\title{
Exocrine pancreatic insufficiency in type 1 and type 2 diabetes mellitus: do we need to treat it? A systematic review
}

\author{
Gábor Zsóri*, Dóra Illés, Viktória Terzin, Emese Ivány, László Czakó \\ University of Szeged, Faculty of Medicine, Albert Szent-Györgyi Medical and Pharmaceutical Center, First Department of Medicine, Szeged, Korányi Fasor 8-
} 10, H-6720, Hungary

\section{A R T I C L E I N F O}

\section{Article history:}

Received 16 November 2017

Received in revised form

11 May 2018

Accepted 12 May 2018

Available online $\mathrm{xxx}$

Keywords:

Diabetes mellitus

Pancreatic enzyme replacement therapy

Pancreatic exocrine insufficiency

Steatorrhea

\begin{abstract}
A B S T R A C T
The exocrine and endocrine pancreata are very closely linked both anatomically and physiologically. Abdominal symptoms such as nausea, bloating, diarrhea, steatorrhea, and weight loss can often occur in diabetic patients. Impairments of the exocrine pancreatic function seem to be a frequent complication of diabetes mellitus; however, they are largely overlooked. The aim of this paper is to provide an overview of the current concepts of exocrine pancreatic insufficiency (PEI) in diabetes mellitus. The prevalence and symptoms of PEI in diabetes mellitus, the pathomechanism, and difficulties of diagnosis and therapy of PEI are summarized in this systematic review.

(c) 2018 IAP and EPC. Published by Elsevier B.V. All rights reserved.
\end{abstract}

\section{Introduction}

The exocrine and endocrine pancreata are very closely linked both anatomically and physiologically. Pathological conditions in the exocrine tissue can therefore cause an impairment of endocrine function and vice versa [1]. Pancreatic exocrine insufficiency (PEI) is defined by a deficiency of exocrine pancreatic enzymes resulting in an inability to maintain normal digestion [2]. The primary function of pancreatic enzymes is the hydrolysis of proteins (trypsinogens, proelastase, mesotrypsin), carbohydrates ( $\alpha$-amylase), lipids (lipase) and nucleotids (DNase, RNase). Chronic pancreatitis is the most common etiology of PEI. Gastrointestinal and pancreatic surgical resections, cystic fibrosis, obstruction of the main pancreatic duct (e.g. pancreatic and ampullary tumors), decreased pancreatic stimulation (e.g. celiac disease), or acid-mediated inactivation of pancreatic enzymes (e.g. Zollinger-Ellison syndrome) can lead to PEI [3]. Furthermore, PEI has been demonstrated to be present in a considerable percentage (10-74\%) of patients with diabetes mellitus [4,5]. However, the significance of this findings was questioned and it is not clear, whether the presence of diabetes causes any symptoms or requires any treatment [6].

Abdominal symptoms such as nausea, bloating, diarrhea,

\footnotetext{
* Corresponding author.

E-mail address: zsori.gabor@med.u-szeged.hu (G. Zsóri).
}

steatorrhea, and weight loss can often occur in diabetic patients [4]. These symptoms may be attributed to the side-effects of the metformin they are taking, the autonomic neuropathy on bowel function, small bowel bacterial overgrowth, celiac disease, or PEI. Impairments of the exocrine pancreatic function seem to be a frequent complication of diabetes mellitus; however, they are largely overlooked. Greater knowledge and awareness are required in testing and diagnosing this condition. Previous studies have raised the possibility that the replacement of pancreatic enzymes in exocrine insufficiency improves related symptoms and may aid glucose control.

The aim of this paper is to provide an overview of the current concepts of PEI in diabetes mellitus.

\section{Search strategy}

The systematic review was conducted following the preferred reporting items for systematic review and meta-analysis protocols (PRISMA-P) 2015 statement [7]. A systematic search was performed in 3 databases, Pubmed, Embase and Cohraine Library. The search included the following MESH terms: "diabetes mellitus" AND "pancreatic function" OR "pancreatic exocrine insufficiency" OR "fecal elastase" OR "secretin" OR "cholecystokinin" OR "steatorrhea" or "pancreatic enzyme replacement therapy". The search was limited to human data and to full text English articles if appropriate. The latest date searched was conducted on the $31 \mathrm{th}$ of January 
2018.

\section{Study selection}

Selection of the studies was conducted by two investigators (G.Zs. and L.C.) separately. Clinical studies were eligible provided that they reported the data of pancreatic exocrine function in adult patients suffering from type 1 and 2 diabetes mellitus. Publications about type III/C diabetes were excluded. Duplicates, repeated publications, publications available only in abstract form, and review papers were excluded. Moreover, articles with inappropriate study design and patient inclusion criteria were also excluded from this systematic review. Remaining studies were further analyzed in full text. The reference list of obtained articles was also checked for additional articles. If differences were found in the reviewer's judgement, then a committee of three other researchers was invited to draw a conclusion. Database searches yielded altogether 1055 articles (EMBASE: 67; PubMed: 701; Cochrane: 287). The flow-chart diagram (Fig. 1) shows the strategy and results of the study selection.

\section{Prevalence of exocrine pancreatic insufficiency in diabetes mellitus}

There have been numerous reports in recent decades on PEI in patients with diabetes mellitus. In the early studies, pancreatic exocrine function was assessed with the gold-standard method of direct pancreatic function tests (pancreozymin-secretin test). PEI was revealed in $52.4 \%(18-100 \%)$ of the cases (Table 1a) [6,8-15]. However, these studies were only limited to a small number of patients because direct pancreatic function tests are invasive, timeconsuming and expensive.

Therefore, a less invasive, cost-effective test was needed to evaluate pancreatic exocrine function in DM. Fecal elastase-1 (FE-1) test measures fecal levels of elastase-1, a proteolytic enzyme produced by pancreatic acinar cells. Fecal level of elastase- 1 correlates with the output of other pancreatic enzymes, it is highly stable in feces and easy to meaure [16]. FE-1 demonstrated good sensitivity and specificity in moderate and severe PEI [17,18]. Nowadays, therefore, FE-1 measurement has become a screening tool in determining PEI. The prevalence of PEI has been demonstrated with FE-1 measurement with an average of $40 \%$ (26-74\%) in type 1 diabetes and with an average of $27 \%(10-56 \%)$ in type 2 diabetes (Table 1b) [4-6,19-32].

The prevalence of PEI in both types of diabetes is very heterogenous. However, most of these studies did not exclude cases with previous pancreatic disease, thus leading to a possible bias. In two recent studies, the prevalence of PEI in DM was less frequent than in previous studies, probably because pancreatic (type 3c, according to the new classification of American Diabetes Association: type 4 [33]) diabetes was excluded [28,29]. Low FE-1 was measured in only $5.4 \%$ of 150 consecutive type 1 and 2 diabetic patients after excluding patients with excessive alcohol consumption, medical history of abdominal surgery, other known reasons for malabsorption, previous pancreatic disease and DM lasting $<5$ years [28]. In another recent study, PEI was diagnosed with FE-1 measurement in $16.8 \%$ of type 2 diabetic patients after excluding patients with an abnormal pancreatic morphology [29]. Indeed, the prevalence of chronic pancreatic diseases among diabetic patients might be high because recent discussions have suggested that pancreatic diabetes (type 4) has been underestimated in the past and that it might cause about $8 \%$ of all diabetes cases [34].

\section{Prevalence of morphologic changes of the exocrine pancreas in diabetes mellitus}

Several studies have examined the morphologic changes of the exocrine pancreas in DM. In nearly 50\% of type 1 DM patients, the pancreas is atrophic and fibrotic, with fatty infiltration and loss of acinar cells on histological examination $[35,36]$. Reduced pancreas size in patients with DM was demonstrated by abdominal ultrasonography, computed tomography or magnetic resonance imaging (MRI) [37-43]. Ductal changes are detected by endoscopic retrograde cholangiopancreatography in $76 \%$ of diabetics.
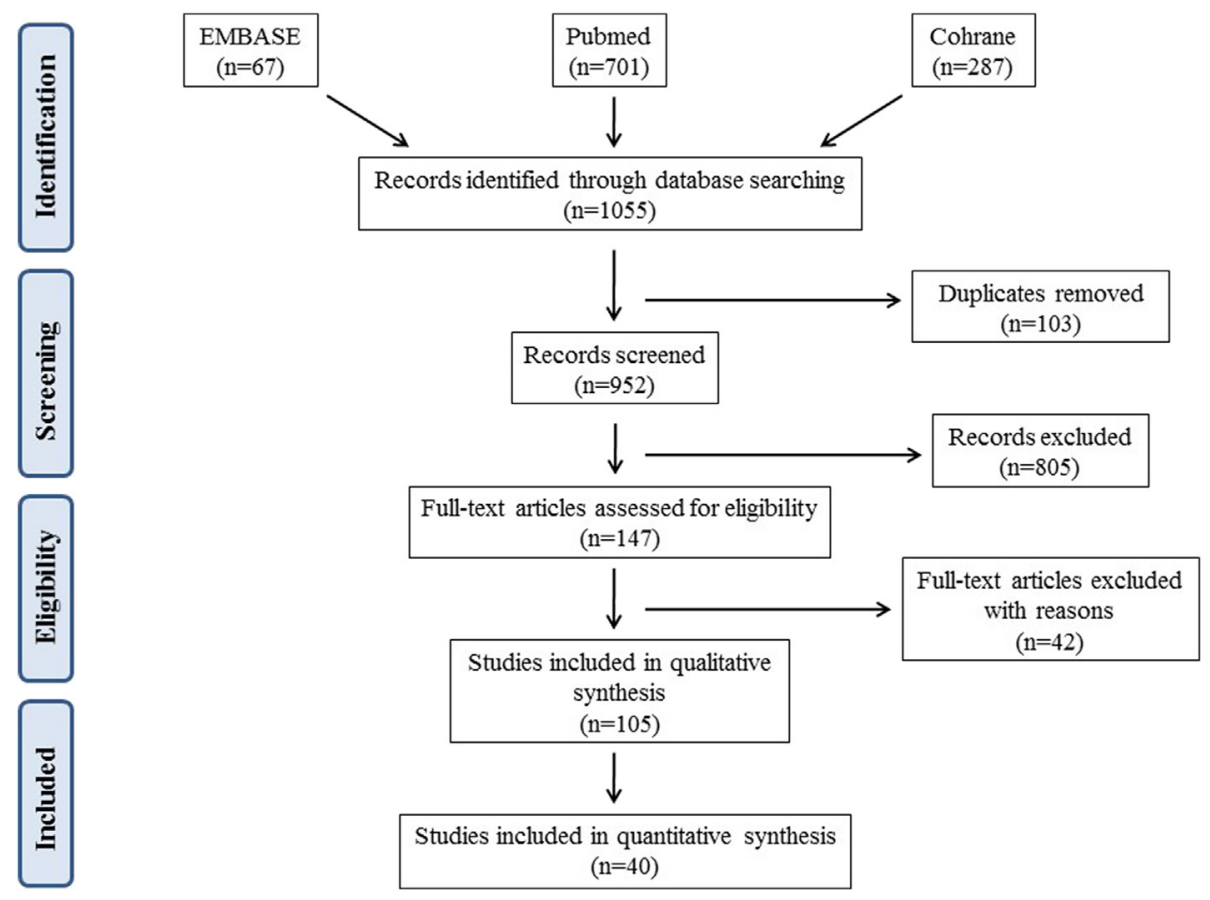

Fig. 1. The flow-chart diagram shows the strategy of the study selection. 
Table 1A

Results of direct pancreatic function tests in patients with diabetes mellitus.

\begin{tabular}{|c|c|c|c|}
\hline Author & Subjects/diabetes type & Methods & Results \\
\hline Pollard et al., 1943 [8] & 13 & $\begin{array}{l}\text { Amylase and lipase after } \\
\text { pancreozymin-secretin stimulation }\end{array}$ & $62 \%$ reduced \\
\hline Chey et al., 1963 [9] & $\begin{array}{l}50 \text { diabetic patients; } 13 \text { juvenile } \\
\text { type }\end{array}$ & $\begin{array}{l}\text { Amylase and lipase after } \\
\text { pancreozymin-secretin stimulation }\end{array}$ & $\begin{array}{l}\text { Low amylase output in diabetes: } 36 \% \text {; } \\
\text { in juvenile diabetes: } 77 \%\end{array}$ \\
\hline Vacca et al., 1964 [10] & $\begin{array}{l}55 \text { diabetic patients } \\
\text { ( } 22 \text { insulin-treated) }\end{array}$ & $\begin{array}{l}\text { Diastase and bicarbonate after secretin } \\
\text { stimulation; fecal fat }\end{array}$ & $\begin{array}{l}73 \% \text { abnormal; correlation with age, no } \\
\text { correlation with fecal fat }\end{array}$ \\
\hline Frier et al., 1976 [11] & 20 type 1,7 type 2,13 controls & Stimulation with iv secretin and CCK-PZ & $\begin{array}{l}\text { PEI: } 80 \% \text { IDDM; correlation with } \\
\text { diabetes duration }\end{array}$ \\
\hline Harano et al., 1978 [12] & 53 type 2,4 type 1,18 controls & Secretin-pancreozymin test & $\begin{array}{l}\text { Diabetes: } 69 \% \text { deficient enzyme output; } \\
\text { correlation with diabetes control }\end{array}$ \\
\hline Lankisch et al., 1982 [13] & 53 type 1 & Secretin-pancreozymin test & Diabetes: $43 \%$ impaired function \\
\hline Bretzke et al., 1984 [14] & $\begin{array}{l}60 \text { insulin-treated type } 2 \\
\text { diabetic patients }\end{array}$ & Secretin-pancreozymin test & Diabetes: 27\% “mild PEI” \\
\hline El Newihi et al., 1988 [15] & $\begin{array}{l}10 \text { type } 2 \text { diabetic patients with } \\
\text { diarrhea and neuropathy }\end{array}$ & Secretin and CCK test & $\begin{array}{l}\text { Enzyme and bicarbonate reduction in } \\
\text { all subjects }\end{array}$ \\
\hline Hahn et al., 2008 [6] & 33 type 1 & Secretin and CCK test & $33 \%$ mild enzyme reduction \\
\hline
\end{tabular}

CCK-PZ: Cholecystokinin-pancreozymin; IDDM: Insulin-dependent diabetes mellitus; PEI: Exocrine pancreatic insufficiency.

Table 1B

Results of indirect pancreatic function tests in patients with diabetes mellitus.

\begin{tabular}{|c|c|c|c|}
\hline Author & Subjects/diabetes type & Methods & Results \\
\hline \multirow[t]{2}{*}{ Hardt and Kloer 1998 [19] } & 128 type 1 and 2 & Fecal chymotrypsin & $45 \%<6 \mathrm{U} / \mathrm{I}$ \\
\hline & & Fecal elastase 1 & $46 \%<200 \mu \mathrm{g} / \mathrm{g}$ \\
\hline \multirow[t]{2}{*}{ Hardt et al., 2000 [5] } & 39 type 1 & Fecal elastase 1 & $74 \%<200 \mu \mathrm{g} / \mathrm{g}$ \\
\hline & 77 type 2 & & $36 \%<200 \mu \mathrm{g} / \mathrm{g}$ \\
\hline Icks et al., 2001 [20] & 112 type 1 & Fecal elastase 1 & $54.5 \%<200 \mu \mathrm{g} / \mathrm{g}$ \\
\hline Rathmann et al., 2001 [21] & 544 type 2 & Fecal elastase 1 & $30.3 \%<200 \mu \mathrm{g} / \mathrm{g}$ \\
\hline \multirow[t]{2}{*}{ Hardt et al., 2003 [22] } & 323 type 1 & Fecal elastase 1 & $51 \%<200 \mu \mathrm{g} / \mathrm{g}$ \\
\hline & 697 type 2 & & $35 \%<200 \mu \mathrm{g} / \mathrm{g}$ \\
\hline Nunes et al., 2003 [23] & 42 type 1 and 2 & Fecal elastase 1 & $36 \%<200 \mu \mathrm{g} / \mathrm{g}$ \\
\hline Cavalot et al., 2004 [24] & 66 type 1 & Fecal elastase 1 & $26 \%<200 \mu \mathrm{g} / \mathrm{g}$ \\
\hline Yilmaztepe et al., 2005 [25] & 32 type 2 & Fecal elastase 1 & $28 \%<200 \mu \mathrm{g} / \mathrm{g}$ \\
\hline Ewald et al., 2007 [26] & 546 type 2 & Fecal elastase 1 & $21.1 \%<100 \mu \mathrm{g} / \mathrm{g}$ \\
\hline Hahn et al., 2008 [6] & 33 type 1 & Fecal elastase 1 & $33 \%<200 \mu \mathrm{g} / \mathrm{g}$ \\
\hline Larger et al., 2012 [27] & 195 type 1,472 type 2 & Fecal elastase 1 & $23 \%<200 \mu \mathrm{g} / \mathrm{g}$ \\
\hline Vujasinovic et al., 2013 [28] & 50 type 1,100 type 2 & Fecal elastase 1 & $5.4 \%<200 \mu \mathrm{g} / \mathrm{g}$ \\
\hline Terzin et al., 2014 [29] & 101 type 2 & Fecal elastase 1 & $16.8 \%<200 \mu \mathrm{g} / \mathrm{g}$ \\
\hline Cummings et al., 2015 [4] & 288 type 2 & Fecal elastase 1 & $10 \%<200 \mu \mathrm{g} / \mathrm{g}$ \\
\hline Shivaprasad et al., 2015 [30] & 89 type 1,95 type 2 & Fecal elastase 1 & $31 \%<200 \mu \mathrm{g} / \mathrm{g}$ \\
\hline Kangrga et al., 2016 [31] & 315 type 2 & Fecal elastase 1 & $5.1 \%<100 \mu \mathrm{g} / \mathrm{g}$ and $5.1 \%<200 \mu \mathrm{g} / \mathrm{g}$ \\
\hline Oscarsson et al., 2017 [32] & 10 type 1,38 type 2 & Fecal elastase 1 & $33 \%<200 \mu \mathrm{g} / \mathrm{g}$ \\
\hline
\end{tabular}

Interestingly, these ductal changes do not correlate with DM type, DM duration or age (Table 2) [35-48].

\section{Pathophysiology}

The mechanism of exocrine pancreatic insufficiency in diabetes is multifactorial (Fig. 2). Pancreas atrophy is a related event in DM and plays a central role in the development of PEI. (1) Insulin has a trophic effect on pancreatic acinar tissue through the insulin-acinar portal system, so its decreased locally high level could lead to pancreatic atrophy [49]. Moreover, decreased pancreatic volume and PEI were shown to correlate in patients with DM [43,50,51]. (2) Acute hyperglycemia was demonstrated to inhibit basal and cholecystokinin-stimulated pancreatic enzyme secretion with an insulin-independent mechanism [52]. (3) Pancreatic stellate cells (PSCs) play a pivotal role in pancreatic fibrosis. Hyperglycemia was demonstrated to promote proliferation and activation of PSCs and to stimulate collagen production of PSCs via the protein kinase seCp38 mitogen-activated protein kinase pathway, resulting in pancreatic fibrosis [53]. (4) The islet hormones (e.g. glucagon and somatostatin) can regulate exocrine tissue, so the lack of these hormones causes dysregulation of enzyme synthesis and resultant exocrine insufficiency. (5) Diabetic microangiopathy leads to insufficient perfusion through local microangiopathy, resulting in ischemia of the exocrine pancreas, which could lead to pancreatic fibrosis, atrophy and PEI [29]. (6) Autonomic neuropathy may give rise to impaired enteropathic reflexes and PEI [27,54,55]. Moreover, (7) viral infections [56], (8) autoimmunity [57], or (9) genetic changes, as single-base deletion in the variable number of tandem repeats containing exon 11 of the carboxyl ester lipase gene [58] could increase simultaneous damage to exocrine and endocrine tissue.

The higher prevalence of PEI in type 1 diabetes can be explained by the more severe insulin deficiency, longer disease duration, and higher rate of microvascular complications characterized by type 1 DM.

The correlation between diabetes duration and the prevalence of PEI is contradictory. Previous studies have described an association or at least a weak correlation between low FE-1 level in type 2 DM and age of onset of diabetes, relatively long diabetes duration, and relatively high glycosylated hemoglobin (HbA1c) concentration, suggesting that exocrine dysfunction is a long-term complication of diabetes [22,59]. However, studies have demonstrated that there is no relationship between fecal elastase concentration and diabetes duration [60]. Otherwise, an inverse correlation was described between diabetes duration and HbA1c levels, and a positive correlation was reported between C-peptide and FE-1 levels [59]. A long-term follow-up study suggested that a mild to 
Table 2

The prevalence of morphologic changes of the exocrine pancreas in diabetes mellitus.

\begin{tabular}{|c|c|c|c|c|}
\hline Author & Year & Subjects & Methods & Results \\
\hline Blumenthal HT et al. [44] & 1963 & 3821 autopsy cases & Morphology & $\begin{array}{l}\text { Prevalence of pancreatitis: } \\
\text { - In diabetics: } 11.2 \% ; \\
\text { - In non-diabetics: } 5.3 \%\end{array}$ \\
\hline Putzke HP et al. [45] & 1986 & $\begin{array}{l}100 \text { diabetic and } \\
100 \text { non-diabetic } \\
\text { autopsy cases }\end{array}$ & Histopathology & $\begin{array}{l}\text { Lipomatosis: } \\
\text { - In diabetics: } 75 \% \text {; } \\
\text { - In controls: } 60 \%\end{array}$ \\
\hline Gilbeau JP et al. [37] & 1992 & 20 type 1,37 type 2 & CT scans & Pronounced lobulation, small size compared to controls \\
\hline Alzaid A et al. [39] & 1993 & 14 type 1,43 type 2 & Ultrasound & Small size compared to controls; type $1<$ type $2<$ controls \\
\hline Nakanishi K et al. [40] & 1994 & 36 type 1,43 type 2 & ERCP & $\begin{array}{l}\text { Changes like CP: } \\
\text { - type } 1: 40 \% \\
\text { - type } 2: 9 \%\end{array}$ \\
\hline Klöppel G et al. [36] & 1996 & type 1 & Histology & Fibrosis, atrophy, fatty infiltration \\
\hline Foulis AK et al. [35] & 1997 & type 1 & Histology & Fibrosis, atrophy, fatty infiltration \\
\hline Altobelli E et al. [38] & 1998 & 60 type 1 & Ultrasound & Small size compared to controls; dependent on duration \\
\hline Hardt PD et al. [41] & 2002 & 38 type 1,118 type 2 & ERCP & $\begin{array}{l}\text { Changes like } \mathrm{CP} \text { : } \\
\text { type } 1>\text { type } 2 \text {, up to } 75 \%\end{array}$ \\
\hline Williams et al. [47] & 2007 & $\begin{array}{l}12 \text { male patients with type } 1 \text { and } 12 \\
\text { healthy controls }\end{array}$ & MRI & $\begin{array}{l}\text { Pancreatic volume showed a } 48 \% \text { reduction in long-standing } \\
\text { type } 1 \text { diabetes as compared with age-matched normal subjects. }\end{array}$ \\
\hline Bilgin $M$ et al. [42] & 2009 & 82 type 1 and type 2 & MRI/MRCP & Changes like $\mathrm{CP}$ \\
\hline Philippe et al. [43] & 2011 & 24 type 1 and 28 type 2 & CT scans & $\begin{array}{l}\text { The pancreatic volume, } 42 \mathrm{~cm}(25-57 \mathrm{~cm}) \text {, was decreased in } \\
\text { most patients }\end{array}$ \\
\hline Williams et al. [48] & 2012 & $\begin{array}{l}20 \text { male } \\
\text { recent-onset type } 1 \text { diabetes patients } \\
\text { and } 24 \text { male healthy controls }\end{array}$ & MRI & Pancreatic volume is reduced by $26 \%$ in type 1 diabetes \\
\hline Burute N et al. [46] & 2014 & $\begin{array}{l}32 \text { type } 2 \text { and } 50 \text { normoglycemic } \\
\text { individuals }\end{array}$ & MRI & $\begin{array}{l}\text { Patients with type } 2 \text { DM had significantly lower pancreatic } \\
\text { volume than normoglycemic individuals }(\mathrm{p}<0.001)\end{array}$ \\
\hline
\end{tabular}

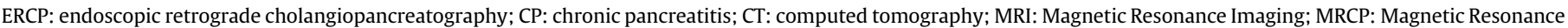
Cholangiopancreatography.

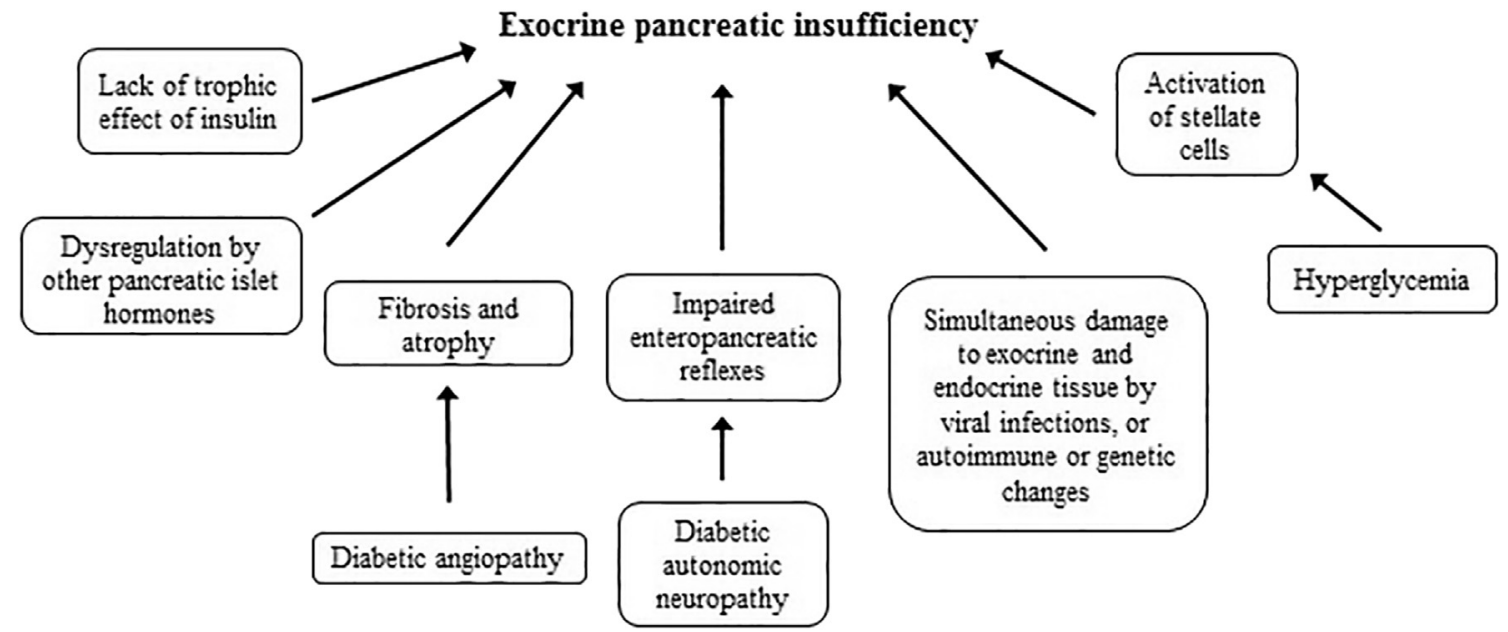

Fig. 2. The mechanism of exocrine pancreatic insufficiency in diabetes mellitus.

moderate exocrine pancreatic insufficiency is due to an early event in the course of DM and does not progress [61].

Nowadays the role of signaling proteins in pancreatic inflammation and diabetes induced pancreatic insufficiency is getting more attention. In a previous study the levels of total PKB, p70S6K, 4 E-BP1, ERK1/2, and NF-kappaB in the diabetic pancreas compared to control were significant decreased, however, the phosphorylation of p70S6K1, $4 \mathrm{E}-\mathrm{BP} 1, \mathrm{ERK} 1 / 2$, and protein ubiquitination were increased significantly compared to control group [62]. Presumable, that these factors are liable for decreased enzyme synthesis and pancreatic atrophy.

\section{Symptoms of PEI in diabetes}

The main clinical symptoms of PEI are due to the maldigestion and malabsorption of fat, including steatorrhea, abdominal pain, flatulence, bloating and weight loss [4]. As a consequence of malnutrition, PEI is associated with low serum levels of micronutrients, lipid soluble vitamins (vitamins A, D, E, and K), trace elements, albumin, prealbumin and lipoproteins [2,29,63-74]. The low level of serum vitamin D leads to osteoporosis and an increased risk of fractures [75]. Protein-energy malnutrition and malabsorption of vitamin D and other micronutrients may result in a higher risk of infection due to their associated effects on innate and adaptive immune responses [76].

Although PEI seems to be frequent in DM, data on the occurrence of the symptoms of PEI in diabetes are limited. Gastrointestinal (GI) symptoms are common (27-87\%) in patients with type 1 and type 2 DM [77-79]. In a recent study by Cummings et al. [4], $24 \%$ of diabetic patients had one or more GI symptoms consistent with a diagnosis of PEI (Bristol stool type 5-7, steatorrhea or weight loss). Among these patients, $42 \%$ had a low FE-1, indicating PEI. It 
can be concluded that FE-1 screening is beneficial in patients with GI symptoms, suggesting the presence of PEI. Furthermore, steatorrhea was a poor marker of PEI in diabetes in this study, since only the minority of patients with steatorrhea had a low fecal elastase level. One would logically expect that diabetic patients with PEI experience weight loss, lower body weight and BMI. However, there were no significant differences in BMI between diabetic patients with a decreased or normal PE-1 concentration [4,29]. Inconsistent with these findings, the size of the pancreas did not correlate with BMI among diabetic patients in another study [37]. Furthermore, PEI detected by low FE- 1 concentrations is frequent even in obese diabetic patients [23,80], and diabetic individuals with excess weight (BMI >25) may be at increased risk for PEI [25].

\section{Diagnosis of PEI}

PEI is suggested by clinical symptoms or poor glycemic control despite an adequate diet, antidiabetic therapy and patient adherence $[24,29]$. Determination of FE- 1 is the most convenient way to diagnose PEI. Decreased FE-1 concentration has previously been demonstrated to be a sensitive method in moderate and severe PEI (sensitivity: $87 \%$ and $95 \%$, respectively) and correlated significantly with the direct pancreatic function test, fat digestion, and the Cambridge severity classification of chronic pancreatitis [81-83]. FE-1 concentration correlates with the severity of PEI: a level of less than $200 \mu \mathrm{g} / \mathrm{g}$ stool indicates moderate PEI, while a level of less than $100 \mu \mathrm{g} / \mathrm{g}$ stool indicates severe PEI [84]. FE-1 is not sufficiently sensitive in mild PEI, but if FE-1 level is decreased, there is a strong chance of revealing changes in the pancreatic duct system and steatorrhea $[83,85]$.

PEI can also be diagnosed with a $13 \mathrm{C}$ mixed triglyceride breath test by measuring the concentration of $13 \mathrm{CO}_{2}$ in expired air after administering the radiolabeled test meal containing a known amount of fat [86]. Its accuracy is similar to FE- 1 in diagnosing PEI [87].

Coefficient of fat absorption (CFA) is another gold standard test for PEI [88], although it has not been evaluated in DM. During the 72 -h stool collection period, the patient consumes $100 \mathrm{~g}$ of fat per day. Fat malabsorption is diagnosed at $>7 \mathrm{~g}$ of fat $/ 100 \mathrm{~g}$ of stool/day, with severe steatorrhea at $\geq 15 \mathrm{~g} /$ day. However, the diet is cumbersome, the 3-day stool collection is inconvenient for both patients and laboratory staff, and therefore CFA is not used in daily clinical practice. It is utilized to evaluate the effectiveness of pancreatic enzyme replacement therapy (PERT) in PEI [89].

Direct pancreatic function tests are considered the gold standard in diagnosing PEI, and they definitely have advantages over indirect tests. However, direct tests are rather time-consuming and expensive to perform, very inconvenient for patients, and only available in a few academic centers.

\section{Therapy}

PERT is applied in PEI to prevent the symptoms of malabsorption, such as steatorrhea, and to provide physiologic nutrition by correcting maldigestion. Only a very limited number of publications have investigated the effectiveness of PERT in PEI associated with diabetes, and the results are contradictory. Three small trials studied the efficacy of PERT in patients with diabetes mellitus secondary to chronic pancreatitis [90,91]. Treatment with PERT demonstrated a significant reduction in post-prandial plasma glucose and glycosylated hemoglobin at 6 months versus baseline values in patients with diabetes due to tropical calculous pancreatitis [92]. In contrast, PERT did not improve mean glucose values; it produced potentially life-threatening disturbances in glucose control among insulin-dependent diabetic patients due to chronic pancreatitis [93]. However, a recent double-blind, randomized, placebo-controlled trial of PERT in patients with PEI due to chronic pancreatitis demonstrated that the efficacy outcomes and adverse event profile for PERT were comparable between patients with and without diabetes [94]. A larger multicenter, double-blind, randomized, placebo-controlled trial demonstrated that PERT was safe, but has no effect on glycemic control in insulin-treated diabetic patients with $\mathrm{FE}-1<100 \mu \mathrm{g} / \mathrm{g}$ [26]. Reduction in mild to moderate hypoglycemic episodes was revealed after 16 weeks of treatment with four capsules of 10000 FIP units of pancreatin with main meals and two capsules of 10000 FIP units of pancreatin with snacks, suggesting a more stable control of insulin therapy. However, this study might be criticized. First, patients were selected according to the presence of PEI irrespective of PEI-related symptoms. Second, the applied dose of pancreatin might be low. Recent guidelines [93-96] recommend a starting dose of PERT to be 50000 IU lipase per main meal and 25000 IU per snack, and this may be titrated up according to symptoms. However, recent evidence suggests that even this dose of PERT may not be sufficient to normalize nutrition [94,97].

Nutrient-induced glucose-dependent insulinotropic polypeptide (GIP) response is diminished in patients with PEI [98]. PERT has been demonstrated to reverse an impaired GIP response and therefore to restore the incretin effect of fat [98]. This effect of PERT may be beneficial in the glycemic control of diabetic patients with PEI.

However, while diabetic patients with reduced FE-1 may not complain about PEI-related gastrointestinal symptoms, they still might suffer from qualitative fat maldigestion, for example, lack of vitamin D, as has been proposed recently [99]. Furthermore, patients with diabetes mellitus have an increased risk of bone fractures [100]. PERT has been demonstrated to increase serum vitamin D level in diabetic patients with PEI, an effect which would be beneficial to reducing the increased risk of bone fracture [26].

However, there are several limitations to this systematic review. Firstly, the prevalence of PEI in both types of diabetes is very heterogenous, ranging between 5.1 and $80 \%$. Secondly, studies applied the gold standard direct pancreatic function test in the measurement of PEI are limited to a small number of patients because of the invasive nature of the test. Thirdly, most of these studies did not exclude cases with previous pancreatic disease, thus leading to a possible bias. Fourth, PEI seems to be frequent in DM, data on the occurrence of the symptoms of PEI in diabetes are limited. Furthermore, only a very limited number of publications have investigated the effectiveness of PERT in PEI associated with diabetes, and the results are contradictory.

\section{Conclusion}

The currently available evidence is limited to answering the question of whether PERT is efficacious in glycemic control in patients with diabetes and PEI. Without doubt, there is a need for further randomized clinical trials in the field. For the moment, we can only suggest searching for PEI in diabetic patients by looking for abdominal symptoms that may be related to PEI and by analyzing serum nutritional factors and vitamin $\mathrm{D}$ level. If the test is positive, a trial of PERT is recommended. The response of abdominal symptoms, serum nutritional factors and parameters of glucose metabolism should be followed. In the case of positive response, long-term PERT is suggested.

\section{Abbreviations}

DM

PEI Exocrine pancreatic insufficiency 


$\begin{array}{ll}\text { FE-1 } & \text { Fecal elastase-1 } \\ \text { HbA1c } & \text { Glycosylated hemoglobin } \\ \text { FIP } & \text { International Pharmaceutical Federation } \\ \text { SCT } & \text { Secretin-cerulein test } \\ \text { PSCs } & \text { Pancreatic stellate cells } \\ \text { GI } & \text { Gastrointestinal } \\ \text { PERT } & \text { Pancreatic enzyme replacement therapy } \\ \text { GIP } & \text { glucose-dependent insulinotropic polypeptide } \\ \text { MRI } & \text { Magnetic Resonance Imaging } \\ \text { CFA } & \text { Coefficient of fat absorption }\end{array}$

\section{References}

[1] Czakó L, Hegyi P, Rakonczay Jr Z, Wittmann T, Otsuki M. Interactions between the endocrine and exocrine pancreas and their clinical relevance. Pancreatology 2009;9:351-9.

[2] Struyvenberg MR, Martin CR, Freedman SD. Practical guide to exocrine pancreatic insufficiency - breaking the myths. BMC Med 2017;15(1):29.

[3] Domínguez-Muñoz JE. Pancreatic exocrine insufficiency: diagnosis and treatment. J Gastroenterol Hepatol 2011;26(2):12-6.

[4] Cummings MH, Chong L, Hunter V, Kar PS, Meeking DR, Cranston ICP. Gastrointestinal symptoms and pancreatic exocrine insufficiency in type 1 and 2 diabetes. Practical Diabetes 2015;32:54-8.

[5] Hardt PD, Krauss A, Bretz L, Porsch-Ozcürümez M, Schnell-Kretschmer H, Mäser E, et al. Pancreatic exocrine function in patients with type-1 and type2 diabetes mellitus. Acta Diabetol 2000;37(3):105-10.

[6] Hahn JU, Kerner W, Maisonneuve P, Lowenfels AB, Lankisch PG. Low fecal elastase 1 levels do not indicate exocrine pancreatic insufficiency in type-1 diabetes mellitus. Pancreas 2008;36:274-8.

[7] Moher D, Shamseer L, Clarke M, Ghersi D, Liberati A, Petticrew M, Shekelle P, Stewart LA. PRISMA-P Group. Preferred reporting items for systematic review and meta-analysis protocols (PRISMA-P) 2015 statement. Syst Rev 2015;4:1. https://doi.org/10.1186/2046-4053-4-1.

[8] Pollard HM, Miller L, Brewer WA. External secretion of the pancreas and diabetes. Am J Dig Dis 1943;10(1):20-3.

[9] Chey WY, Shay H, Shuman CR. External pancreatic secretion in diabetes mellitus. Ann Intern Med 1953;59:812-21.

[10] Vacca JB, Henke WJ, Knight WA. The exocrine pancreas in diabetes mellitus. Ann Intern Med 1964;61:242-7.

[11] Frier BM, Saunders JHB, Wormsley KG, Bouchier IAD. Exocrine pancreatic function in juvenile-onset diabetes mellitus. Gut 1976;17:685-91.

[12] Harano Y, Kim CI, Kang M, Shichiri M, Shimizu Y, Li H, et al. External pancreatic dysfunction associated with diabetes mellitus. J Lab Clin Med 1978;91:780-90.

[13] Lankisch PG, Manthey G, Otto J, Talaulicar M, Willms B, Creutzfeldt W. Exocrine pancreatic function in insulin dependent diabetes mellitus. Digestion 1982:25:210-6.

[14] Bretzke G. Diabetes mellitus und exocrine pancreas function. Zeitschrift fur die Gesamte Innere Medizin und Ihre Grenzgebiete 1984;39(16):388-90.

[15] Newihi EH, Dooley CP, Saad C, Staples J, Zeidler A, Valenzuela JE. Impaired exocrine pancreatic function in diabetics with diarrhea and peripheral neuropathy. Dig Dis Sci 1988;33(6):705-10.

[16] Domínguez-Muñoz JE, D Hardt P, Lerch MM, Löhr MJ. Potential for screening for pancreatic exocrine insufficiency using the fecal Elastase-1 test. Dig Dis Sci 2017;62(5):1119-30.

[17] Lüth S, Teyssen S, Forssmann K, Kölbel C, Krummenauer F, Singer MV. Fecal elastase-1 determination: 'gold standard' of indirect pancreatic function tests? Scand J Gastroenterol 2001;36(10):1092-9.

[18] Martínez J, Laveda R, Trigo C, Frasquet J, Palazón JM, Pérez-Mateo M. Fecal elastase-1 determination in the diagnosis of chronic pancreatitis. Gastroenterol Hepatol 2002;25(6):377-82.

[19] Hardt PD, Kloer HU. Diabetes mellitus and exocrine pancreatic disease. Pancreatic Disease 1998;2:235-41.

[20] Icks A, Haastert B, Giani G, Rathmann W. Low fecal elastase-1 in type I diabetes mellitus. Zeitschrift fur Gastroenterologie 2001;39(10):823-30.

[21] Rathmann W, Haastert B, Icks A, Giani G, Hennings S, Mitchell J, et al. Low fecal elastase 1 concentrations in type 2 diabetes. Scand J Gastroenterol 2001;36:1056-61.

[22] Hardt PD, Hauenschild A, Nalop A, Marzeion AM, Jaeger C, Teichmann J, et al. High prevalence of exocrine pancreatic insufficiency in diabetes mellitus. A multicenter study screening fecal elastase 1 concentrations in 1,021 diabetic patients. Pancreatology 2003;3(5):395-402.

[23] Nunes AC, Pontes JM, Rosa A, Gomes L, Carvalheiro M, Freitas D. Screening for pancreatic exocrine insufficiency in patients with diabetes mellitus. Am J Gastroenterol 2003:98(12):2672-5.

[24] Cavalot F, Bonomo K, Perna P, Bacillo E, Salacone P, Gallo M, et al. Pancreatic elastase- 1 in stools, a marker of exocrine pancreas function, correlates with both residual $\beta$-cell secretion and metabolic control in type 1 diabetic subjects. Diabetes Care 2004;27(8):2052-4.

[25] Yilmaztepe A, Ulukaya E, Ersoy C, Yilmaz M, Tokullugil HA. Investigation of fecal pancreatic elastase-1 levels in type 2 diabetic patients. Turk J
Gastroenterol 2005;16(2):75-80

[26] Ewald N, Bretzel RG, Fantus IG, Hollenhorst M, Kloer HU, Hardt PD. Pancreatin therapy in patients with insulin-treated diabetes mellitus and exocrine pancreatic insufficiency according to low fecal elastase 1 concentrations. Results of a prospective multi-centre trial. Diabetes Metabol Res Rev 2007:23(5):386-91.

[27] Larger E, Philippe MF, Barbot-Trystram L, Radu A, Rotariu M, Nobécourt E et al. Pancreatic exocrine function in patients with diabetes. Diabet Med 2012:29:1047-54.

[28] Vujasinovic M, Zaletel J, Tepes B, Popic B, Makuc J, Epsek LM, et al. Low prevalence of exocrine pancreatic insufficiency in patients with diabetes mellitus. Pancreatology 2013;13:343-6.

[29] Terzin V, Várkonyi T, Szabolcs A, Lengyel C, Takács T, Zsóri G, et al. Prevalence of exocrine pancreatic insufficiency in type 2 diabetes mellitus with poor glycemic control. Pancreatology 2014;14(5):356-60.

[30] Shivaprasad C, Pulikkal AA, Kumar KM. Pancreatic exocrine insufficiency in type 1 and type 2 diabetics of Indian origin. Pancreatology 2015;15(6): $616-9$

[31] Kangrga RN, Ignjatović SD, Dragašević MM, Jovičić SŽ, Majkić-Singh NT. Pancreatic elastase levels in feces as a marker of exocrine pancreatic function in patients with diabetes mellitus. Lab Med 2016;47(2):140-8.

[32] Oscarsson J, Nilsson CA, Kvarnstrom M, Lindkvist B. Type 2 diabetes and pancreatic exocrine function: associations between fecal elastase- 1 levels and gastrointestinal symptoms, plasma nutritional markers, and uptake of free versus esterified omega-3 fatty acids in a randomized, open-label, crossover study. Gastroenterology 2017;152(5). suppl. 1:899.

[33] American Diabetes Association. Classification and diagnosis of diabetes Diabetes Care 2017;40(1):11-24.

[34] Hardt PD, Brendel MD, Kloer HU, Bretzel RG. Is pancreatic diabetes (type 3c diabetes) underdiagnosed and misdiagnosed? Diabetes Care 2008;31:165-9.

[35] Foulis AK, McGill M, Farquharson MA, Hilton DA. A search for evidence of viral infection in pancreases of newly diagnosed patients with IDDM. Diabetologia 1997;40(1):53-61.

[36] Klöppel G, Clemens A. Insulin-dependent diabetes mellitus. Current aspects of morphology, etiology and pathogenesis. Pathologe 1996;17(4):269-75.

[37] Gilbeau JP, Poncelet V, Libon E, Derue G, Heller FR. The density, contour, and thickness of the pancreas in diabetics: CT findings in 57 patients. AJR Am J Roentgenol 1992;159(3):527-31.

[38] Altobelli E, Blasetti A, Verrotti A, Di Giandomenico V, Bonomo L, Chiarelli F. Size of pancreas in children and adolescents with type I (insulin-dependent) diabetes. J Clin Ultrasound 1998;26(8):391-5.

[39] Alzaid A, Aideyan O, Nawaz S. The size of the pancreas in diabetes mellitus. Diabet Med 1993;10(8):759-63.

[40] Nakanishi K, Kobayashi T, Miyashita H, Okubo M, Sugimoto T, Murase T, et al. Exocrine pancreatic ductograms in insulin-dependent diabetes mellitus. Am J Gastroenterol 1994;89(5):762-6.

[41] Hardt PD, Killinger A, Nalop J, Schnell-Kretschmer H, Zekorn T, Klör HU. Chronic pancreatitis and diabetes mellitus. A retrospective analysis of 156 ERCP investigations in patients with insulin-dependent and non-insulindependent diabetes mellitus. Pancreatology 2002;2(1):30-3.

[42] Bilgin M, Balci NC, Momtahen AJ, Bilgin Y, Klör HU, Rau WS. MRI and MRCP findings of the pancreas pancreatic exocrine function determined by fecal elastase 1. J Clin Gastroenterol 2009;43(2):165-70.

[43] Philippe MF, Benabadji S, Barbot-Trystram L, Vadrot D, Boitard C, Larger E. Pancreatic volume and endocrine and exocrine functions in patients with diabetes. Pancreas 2011;40:359-63.

[44] Blumenthal HT, Probstein JG, Berns AW. Interrelationship of diabetes mellitus and pancreatitis. Arch Surg 1963;87:844-50.

[45] Putzke HP, Friedrich G. Pancreatopathy in diabetes mellitus. Zentralbl Allg Pathol 1986;131(1):37-41.

[46] Williams AJ, Chau W, Callaway MP, et al. Magnetic resonance imaging: a reliable method for measuring pancreatic volume in type 1 diabetes. Diabet Med 2007;24:35-40.

[47] Williams AJ, Thrower SL, Sequeiros IM, et al. Pancreatic volume is reduced in adult patients with recently diagnosed type 1 diabetes. J Clin Endocrinol Metab 2012:97:2109-13.

[48] Burute N, Nisenbaum R, Jenkins DJ, Mirrahimi A, Anthwal S, Colak E, et al Pancreas volume measurement in patients with Type 2 diabetes using magnetic resonance imaging-based planimetry. Pancreatology 2014;14(4): $268-74$.

[49] Barreto SG, Carati CJ, Toouli J, et al. The islet-acinar axis of the pancreas: more than just insulin. Am J Physiol Gastrointest Liver Physiol 2010;299(1): $10-22$.

[50] Goda K, Sasaki E, Nagata K, Fukai M, Ohsawa N, Hahafusa T. Pancreatic volume in type 1 and type 2 diabetes mellitus. Acta Diabetol 2001;38:145-9.

[51] Löhr M, Klöppel G. Residual insulin positivity and pancreatic atrophy in relation to duration of chronic type 1 (insulin-dependent) diabetes mellitus and microangiopathy. Diabetologia 1987;30:757-62.

[52] Lam WF, Gielkens HA, Coenraad M, Souverijn JH, Lamers CB, Masclee AA. Effect of insulin and glucose on basal and cholecystokinin-stimulated exocrine pancreatic secretion in humans. Pancreas 1999;18:252-8.

[53] Nomiyama Y, Tashiro M, Yamaguchi T, Watanabe S, Taguchi M, Asaumi $\mathrm{H}$, et al. High glucose activates rat pancreatic stellate cells through protein kinase $C$ and p38 mitogen-activated protein kinase pathway. Pancreas 2007;3: 364-72 
[54] Hardt PD, Ewald N. Exocrine pancreatic insufficiency in diabetes mellitus: a complication of diabetic neuropathy or a different type of diabetes? Exp Diabetes Res 2011;2011:761950.

[55] el Newihi H, Dooley CP, Saad C, Staples J, Zeidler A, Valenzuela JE. Impaired exocrine pancreatic function in diabetics with diarrhea and peripheral neuropathy. Dig Dis Sci 1988;33(6):705-10.

[56] Gamble DR, Taylor KW. Coxsackie B virus and diabetes. Br Med J 1973;3(1): 289-90.

[57] Kobayashi T, Nakanishi K, Kajio H, Morinaga S, Sugimoto T, Murase T, et al. Pancreatic cytokeratin: an antigen of pancreatic exocrine cell autoantibodies in type 1 (insulin-dependent) diabetes mellitus. Diabetologia 1990;33(6): 363-7.

[58] Raeder H, Johansson S, Holm PI, Haldorsen IS, Mas E, Sbarra V, et al. Mutations in the CEL VNTR cause a syndrome of diabetes and pancreatic exocrine dysfunction. Nat Genet 2006;38(1):54-62.

[59] Ewald N, Raspe A, Kaufmann C, Bretzel RG, Kloer HU, Hardt PD. Determinants of exocrine pancreatic function as measured by fecal elastase-1 concentrations (FEC) in patients with diabetes mellitus. Eur J Med Res 2009;14(3): $118-22$.

[60] Rathmann W, Haastert B, Glasbrenner BJ, Berglind N, Nicholas J, Wareham NJ. Inverse association of HbA1c with faecal elastase 1 in people without diabetes. Pancreatology 2015;15(6):620-5.

[61] Creutzfeldt W, Gleichmann D, Otto J, Stockmann F, Maisonneuve P, Lankisch PG. Follow-up of exocrine pancreatic function in type-1 diabetes mellitus. Digestion 2005;72:71-5.

[62] Patel R, Atherton P, Wackerhage H, Singh J. Signaling proteins associated with diabetic-induced exocrine pancreatic insufficiency in rats. Ann N Y Acad Sci 2006 Nov;1084:490-502.

[63] Lindkvist B, Domínguez-Muñoz JE, Luaces-Regueira M, CastiñeirasAlvariño M, Nieto-Garcia L, Iglesias-Garcia J. Serum nutritional markers for prediction of pancreatic exocrine insufficiency in chronic pancreatitis. Pancreatology 2012;12:305-10.

[64] Hartmann D, Felix K, Ehmann M, et al. Protein expression profiling reveals distinctive changes in serum proteins associated with chronic pancreatitis. Pancreas 2007;35(4):334-42.

[65] Haas S, Krins S, Knauerhase A, Löhr M. Altered bone metabolism and bone density in patients with chronic pancreatitis and pancreatic exocrine insufficiency. JOP 2015;16(1):58-62.

[66] Sikkens EC, Cahen DL, Koch AD, Braat H, Poley JW, Kuipers EJ, Bruno MJ. The prevalence of fat-soluble vitamin deficiencies and a decreased bone mass in patients with chronic pancreatitis. Pancreatology 2013;13(3):238-42.

[67] Johnson EJ, Krasinski SD, Howard LJ, Alger SA, Dutta SK, Russell RM. Evaluation of vitamin A absorption by using oil-soluble and water-miscible vitamin A preparations in normal adults and in patients with gastrointestinal disease. Am J Clin Nutr 1992:55:857-64.

[68] Nakamura T, Takebe K, Imamura K, Tando Y, Yamada N, Arai Y, et al. Fatsoluble vitamins in patients with chronic pancreatitis (pancreatic insufficiency). Acta Gastroenterol Belg 1996:59:10-4.

[69] Teichmann J, Mann ST, Stracke H, Lange U, Hardt PD, Klor HU, et al. Alterations of vitamin D3 metabolism in young women with various grades of chronic pancreatitis. Eur J Med Res 2007;12:347-50.

[70] Dujsikova H, Dite P, Tomandl J, Sevcikova A, Precechtelova M. Occurrence of metabolic osteopathy in patients with chronic pancreatitis. Pancreatology 2008;8:583-6.

[71] Domínguez-Muñoz JE, Iglesias-García J, Vilariño-Insua M, Iglesias-Rey M. 13C-mixed triglyceride breath test to assess oral enzyme substitution therapy in patients with chronic pancreatitis. Clin Gastroenterol Hepatol 2007;5 484-8.

[72] Girish BN, Rajesh G, Vaidyanathan K, Balakrishnan V. Zinc status in chronic pancreatitis and its relationship with exocrine and endocrine insufficiency JOP 2009; $10: 651-6$

[73] Dutta SK, Procaccino F, Aamodt R. Zinc metabolism in patients with exocrine pancreatic insufficiency. J Am Coll Nutr 1998;17:556-63.

[74] Glasbrenner B, Malfertheiner P, Buchler M, Kuhn K, Ditschuneit H. Vitamin B12 and folic acid deficiency in chronic pancreatitis: a relevant disorder? Klin Wochenschr 1991;69:168-72.

[75] Tignor AS, Wu BU, Whitlock TL, Lopez R, Repas K, Banks PA, et al. High prevalence of low-trauma fracture in chronic pancreatitis. Am J Gastroenterol 2010;105(12):2680-6.

[76] Bresnahan KA, Tanumihardjo SA. Undernutrition, the acute phase response to infection, and its effects on micronutrient status indicators. Adv Nutr 2014:5(6):702-11.

[77] Gustafsson RJ. Esophageal dysmotility is more common than gastroparesis in diabetes mellitus and is associated with retinopathy. Rev Diabet Stud 2011:8:268-75.

[78] Krishnan B, Babu S, Walker J, Walker AB, Pappachan JM. Gastrointestinal complications of diabetes mellitus. World J Diabetes 2013;4(3):51-63.

[79] Koch CA, Uwaifo GI. Are gastrointestinal symptoms related to diabetes mellitus and glycemic control? Eur J Gastroenterol Hepatol 2008;20(9): $822-5$.

[80] Teichmann J, Riemann JF, Lange U. Prevalence of exocrine pancreatic insufficiency in women with obesity syndrome: assessment by pancreatic fecal elastase 1. ISRN Gastroenterol 2011:951686.

[81] Löser C, Möllgaard A, Fölsch UR. Faecal elastase 1: a novel, highly sensitive, and specific tubeless pancreatic function test. Gut 1996;39:580-6.

[82] Leeds JS, Oppong K, Sanders DS. The role of fecal elastase 1 in detecting exocrine pancreatic disease. Nat Rev Gastroenterol Hepatol 2011;8:405-15.

[83] Hardt PD, Marzeion AM, Schnell-Kretschmer H, Wüsten O, Nalop J, Zekorn T, et al. Fecal elastase 1 measurement compared with endoscopic retrograde cholangiopancreatography for the diagnosis of chronic pancreatitis. Pancreas 2002;25:6-9.

[84] Dominguez-Munoz JE, Hieronymus C, Sauerbruch T, Malfertheiner P. Fecal elastase test: evaluation of a new noninvasive pancreatic function test. Am J Gastroenterol 1995;90:1834-7.

[85] Hardt PD, Hauenschild A, Jaeger C, Teichmann J, Bretzel RG, Kloer HU, et al. High prevalence of steatorrhea in 101 diabetic patients likely to suffer from exocrine pancreatic insufficiency according to low fecal elastase 1 concentrations: a prospective multicenter study. Dig Dis Sci 2003;48:1688-92.

[86] Domínguez-Muñoz JE, Nieto L, Vilariño M, Lourido MV, Iglesias-García J. Development and diagnostic accuracy of a breath test for pancreatic exocrine insufficiency in chronic pancreatitis. Pancreas 2016;45(2):241-7.

[87] González-Sánchez V, Amrani R, González V, Trigo C, Picó A, de-Madaria E. Diagnosis of exocrine pancreatic insufficiency in chronic pancreatitis: 13Cmixed triglyceride breath test versus fecal elastase. Pancreatology 2017; 17(4):580-5.

[88] Lindkvist B. Diagnosis and treatment of pancreatic exocrine insufficiency. World J Gastroenterol 2013;19(42):7258-66.

[89] Berry AJ. Pancreatic enzyme replacement therapy during pancreatic insufficiency. Nutr Clin Pract 2014;29:312-21.

[90] Mohan V, Poongothai S, Pitchumoni CS. Oral pancreatic enzyme therapy in the control of diabetes mellitus in tropical calculous pancreatitis. Int J Pancreatol 1998;24(1):19-22.

[91] O'Keefe SJ, Cariem AK, Levy M. The exacerbation of pancreatic endocrine dysfunction by potent pancreatic exocrine supplements in patients with chronic pancreatitis. J Clin Gastroenterol 2001;32(4):319-23.

[92] Whitcomb DC, Bodhani A, Beckmann K, Sander-Struckmeier S, Liu S, Fuldeore M, et al. Efficacy and safety of pancrelipase/pancreatin in patients with exocrine pancreatic insufficiency and a medical history of diabetes mellitus. Pancreas 2016;45(5):679-86.

[93] Working Party of the Australasian Pancreatic Club, Smith RC, Smith SF, Wilson J, Pearce C, Wray N, et al. Summary and recommendations from the Australasian guidelines for the management of pancreatic exocrine insufficiency. Pancreatology 2016;16(2):164-80.

[94] Löhr JM, Oliver MR, Frulloni L. Synopsis of recent guidelines on pancreatic exocrine insufficiency. United European Gastroenterol J 2013;1(2):79-83.

[95] Thorat V, Reddy N, Bhatia S, Bapaye A, Rajkumar JS, Kini DD, et al. Randomised clinical trial: the efficacy and safety of pancreatin enteric-coated minimicrospheres (Creon 40000 MMS) in patients with pancreatic exocrine insufficiency due to chronic pancreatitis - a double-blind, placebocontrolled study. Aliment Pharmacol Ther 2012;36:426-36.

[96] Dominguez Munoz JE, Iglesias-Garcia J, Vilarino-Insua M, Iglesias-Rey M. 13C-mixed triglyceride breath test to assess oral enzyme substitution therapy in patients with chronic pancreatitis. Clin Gastroenterol Hepatol 2007;5: 484-8.

[97] Sikkens EC, Cahen DL, van Eijck C, Kuipers EJ, Bruno MJ. Patients with exocrine insufficiency due to chronic pancreatitis are undertreated: a Dutch national survey. Pancreatology 2012;12(1):71-3.

[98] Ebert R, Creutzfeldt W. Reversal of impaired GIP and insulin secretion in patients with pancreatogenic steatorrhea following enzyme substitution. Diabetologia 1980;19(3):198-204.

[99] Teichmann J, Lange U, Hardt P. Decreased pancreatic elastase 1 content: an independent risk factor of the osteoporosis in elderly women. Bone 2001;28: S194.

[100] Jackuliak P, Payer J. Osteoporosis, fractures, and diabetes. Internet J Endocrinol 2014:820615. 